\title{
METHYLATION OF LIVER DNA OF RAT AND MOUSE BY $N$-NITROSODIMETHYLAMINE FORMED IN VIVO FROM DIMETHYLAMINE AND NITRITE*
}

\author{
A. Meier-Bratschi, W. K. Lutz ${ }^{\dagger}$ and Ch. Schlatter \\ Insritut für Toxiknlogie der Eidgenössischen Technischen Hochschule und der Universität Zürich. \\ CH-860)3 Schwerzenbach. Switzerland
}

(Received 29 July: 1982: rerision receited 31 August 1982)

\begin{abstract}
The extent of formation of $N$-nitrosodimethylamine (NDMA) in the stomachs of rats and mice after simultancous oral administration of $\left[{ }^{14} \mathrm{C}\right]$ dimethylamine and potassium nitrite was determined by measuring the methylation of liver DNA. With doses of around I mg dimethylaminc hydrochloride $/ \mathrm{kg}$ body weight and $50 \mathrm{mg}$ potassium nitrite $/ \mathrm{kg}$ body weight. $0.8 \%$, of the amine was nitrosited on average. The individual huctuations ranged from 0.2 to $1.3^{\circ}$, in the rat and from 0.2 to $1.9^{\prime \prime} .$, in the mouse. Simultaneous administration of $50 \mathrm{mg}$ sodium ascorbate (vitamin $\mathrm{C}$ )/kg body weight inhibited the nitrosation by about $80^{\circ}$, while $50 \mathrm{mg} \alpha$-tocopherol acetate (vitamin E)/kg body weight reduced the nitrosation by about a half. Assuming similar kinetics and conditions of nitrosation in rats and man. a comparison of the formation of NDMA in tilo from dietary dimethylamine and nitrite with the estimated human uptake of preformed NDMA revealed that in vito formation in the stomach of man is probably negligible.
\end{abstract}

\section{INTRODUCTION}

The generation of nitrosamines from the reaction of amines with nitrite and their carcinogenicity in animals and man is widely discussed (IARC. 1980). The nitrosation of dimethylamine (DMA) is particularly important because this amine is a ubiquitous dietary constituent and its nitrosation product, $N$-nitrosodimethylamine (NDMA). is a strong carcinogen. The reaction kinetics and $\mathrm{pH}$-dependence, as well as the inhibitors and catalysts, of this nitrosation reaction in citro are relatively well known (Mirvish, 1975), but few quantitative data are available on the extent of NDMA formation in tivo. However, such information would be needed for a risk assessment in man. Rounbehler, Ross, Fine et al. (1977) determined the NDMA content of whole frozen mice after treatment with DMA and nitrite. Histological damage to the liver from such treatment has also been reported (Asahina, Friedman, Arnold et al. 1971; Cardesa, Mirvish, Haven \& Shubik, 1974; Pollard, Sharon \& Chang, 1972) but in no case was the extent of the nitrosation estimated. Braun attempted to determine the in vito nitrosation of amines using the mutagenic properties of the nitrosamines. However, no mutagenicity was

Ahbretiations: DMA = dimethylamine: $\mathrm{HPLC}=$ highperformance liquid chromatography: $\mathrm{NDMA}=\mathrm{N}$ nitrosodimethylamine: TLC = thin-layer chromatography.

* Preliminary results of this work have been published at the 12th Annual Meeting of the Union of Swiss Societies of Experimental Biology, 13-14 March 1980 in Basel. Switzerland. and at the 92nd Annual Mceting of the Swiss Society for Analytical and Applied Chemistry. 12.13 September 1980 in Zürich.

tTo whom all correspondence should be addressed. detected in their host-mediated Ames test in mice treated with DMA and equimolar nitrite (Braun. Schöneich \& Ziebarth, 1977).

The carcinogenicity of the nitrosamines seems to result from the covalent interaction of their chemically reactive metabolites or breakdown products with DNA in the target cell. NDMA leads to the methylation of DNA at more than a dozen different positions. About $80 \%$ of these methylations occur at the nitrogen-7 atom of guanine (Lawley, 1976; Singer. 1975). Determination of this DNA damage could therefore be used as an indicator of nitrosamine formation in vivo.

Here, we report the results of a study on the formation of 7-methylguanine in liver DNA of rats and mice after simultaneous oral administration of $\left[{ }^{14} \mathrm{C}\right]$ dimethylamine and nitrite. The level of DNA methylation was compared with that reached after administration of the presumed nitrosation reaction product. NDMA. We also tested whether this reaction could be inhibited by administration of the antioxidants vitamin $C$ (sodium ascorbate) or vitamin $E$ ( $x$-tocopherol acetate). These substances are often discussed as inhibitors of nitrosamine formation (IARC, 1980). The mechanism of the inactivation of nitrite by vitamin $C$ was studied by Dahn, Loewe \& Bunton (1960).

\section{EXPERIMENTAL}

Materials. Potassium nitrite, sodium ascorbate and x-tocopherol acetate were purchased from Fluka AG (Buchs). Radioactive compounds were purchased from The Radiochemical Centre, Amersham. Bucks, England. $\left[{ }^{1+} \mathrm{C}\right]$ Dimethylamine. $\mathrm{HCl}$ had a specific activity of $54 \mathrm{mCi} / \mathrm{mmol}$ and a radiochemical purity of 
$98^{\circ}$ " as determined by thin-layer chromatography (TLC) on Cellulose $F_{2.54}$ aluminium foils (E. Merck GmbH, Darmstadt. FRG), using a solvent mixture of isopropanol ethanol $1 \mathrm{v}-\mathrm{HCl}(75: 75: 50$. by vol.) as the eluant and ninhydrin reagent for detection. ${ }^{14} \mathrm{C}$-labelled NDMA had a specific activity of $7.5 \mathrm{mCi} / \mathrm{mmol}$ and a radiochemical purity of $96^{\prime \prime}$. as determined by TLC on Silica Gel GF ${ }_{244}$ (E. Merck $\mathrm{GmbH}$ ). using hexane ether-methylene chloride (40:30:20, by vol.) as the eluant. Hydroxyapatite came from Bio-Rad Laboratories, Richmond. CA (Bio-Gel HTP DNA-grade. selected batches for high yields). Insta-Gel scintillation cocktail was from Packard Instruments Co., Frankfurt, FRG. ${ }^{14} \mathrm{C}$ radioactivity was measured in a Berthold Betaszint 5000$)$ liquid scintillation counter. DNA samples and purinebase fractions were counted in low-background Beckman glass vials. Counting efficiency was determined by the external standard method after calibration with $\left[{ }^{1+} \mathrm{C}\right]$ hexadecane standard.

Animals and treatments. Young adult male rats (ZUR:SIV-Z. Sprague Dawley derived. 200-300 g) and mice (NMRI, $22 \cdot 35 \mathrm{~g}$ ) were used throughout. The animals were housed in macrolone cages and were given water and food (Laboratory chow, pellets No. 890; Nafag AG. Gossalul ad lib. Administrations of test solutions by oral gavage $111.5 \mathrm{ml}$ and $(0.51 .() \mathrm{ml}$ for rats and mice. respectivelyl were always performed between 9 and 10 a.m. After $6 \mathrm{hr}$ the animals were killed by open heart puncture under ether anaesthesia and their livers were removed and processed immediately by homogenization in a Waring blender.

Stock solutions of $50 \mathrm{mg} / \mathrm{ml}$ potassium nitrite or sodium ascorbate were prepared in deionized water. $x$-Tocopherol acetate $(500 \mathrm{mg})$ was dissolved in $3 \mathrm{ml}$ ethanol and mixed with water up to $10 \mathrm{ml}$ to produce a fine suspension. Stock solutions were mixed in small tubes on a balance on the basis of each animal's weight. An aliquot of the radiolabelled compound dissolved in water was added and the exact amount of radioactivity administered was determined by weighing the syringe before and after gavalge and by measuring the specific activity of the solution administered. The dose $(\mathrm{mg} / \mathrm{kg})$ of the radiolabelled compound was calculated on the basis of the specitic activity as stated by the supplier.

Isolation of DNA. Liver DNA was isolated according to Markov \& Ivanov (1974) with minor modifications as described in Viviani \& Lutz (1978). Liver homogenate was deproteinated with a mixturc of chloroform $(480 \mathrm{ml})$. isoamyl alcohol $(20 \mathrm{ml})$ and phenol (added with stirring to give a volume of 1 litre). and the DNA was purified by adsorption chromatography on hydroxyapatite. After dialysis against deionized water and precipitation with ethanol. the DNA was dissolved in $0.014 \mathrm{~m}$-phosphate buffer. The specific activity of the DNA was determined by counting the ${ }^{1+} \mathrm{C}$ activity in $10 \mathrm{ml}$ Insta-Gel and by quantitative spectrophotometric determination of the DNA at $260 \mathrm{~nm}$ (absorbance was 20 for a solution of $1 \mathrm{mg} \mathrm{DNA} / \mathrm{ml}$ buffer).

Purine-hase analysis. DNA was hydrolysed for $1 \mathrm{hr}$ at $70^{\circ} \mathrm{C}$ with $0.1 \mathrm{~N}-\mathrm{HCl}$ to liberate the purines (Lawley. 1976). 7-Methylguanine was added as a standard (Sigma Chemical Co.. St Louis, MO) and the mixture (about $100 \mu \mathrm{g}$ hydrolysed DNA) was separated by reverse-phase HPLC on a Packard 1084 chromatograph with a $\mu$ Bondapak $C_{14}$ column. $300 \times 4 \mathrm{~mm}$ (Waters Associates. Milford. MA). Elution with a $0.01 \mathrm{~m}$-ammonium phosphate buffer. $\mathrm{pH} 4$. containing $1^{\circ}$ " methanol at a flow rate of $1.2 \mathrm{ml} / \mathrm{min}$ was monitored spectrophotometrically at $260 \mathrm{~nm}$. Fractions of $12 \mathrm{ml}$ were collected and ${ }^{1+} \mathrm{C}$ radlioactivity was counted.

Statistics. To assess the statistical significance of effects, the probability of equality was catculated on the basis of a onc-sided Student's I test. corrected, if necessary, for inequality of the variance.

\section{RESULTS}

Radioactivity on the DNA of an animal treated with a radiolabelled substance is not necessarily due to covalent interactions of the test compound with DNA. Besides non-covalent interactions with DNA or contamination of the DNA with RNA or proteins, it is also possible that biosynthetic incorporation of radioactivity will occur if the radiolabelled compound is degradable to small molecules able to enter the pool of nucleic acid precursors. Such is obviously the case with single-carbon fragments generated in the metabolism of DMA and NDMA. and it is therefore not surprising that liver DNA was found to be radiolabelled even when DMA was administered without nitrite (see Tables 1 and 2 for rat and mouse. respectively). The specific activity of these DNA samples $(4.50 \mathrm{dpm} / \mathrm{mg})$ was, however. not high enough 10 allow for a purine-base HPLC analysis to determine what fraction of the total DNA radioactivity wass incorporated into natural purines or was eluting as 7-methylguanine.

In experiment 2, a roughly fifty-fold molar cxcess of potassium nitrite was administered simultaneously with DMA. The radioactivity in whole liver DNA in all animals was higher than in experiment 1. This increase in radioactivity in wholc DNA is no proof on its own of the generation of a methylating agent. It is also possible that this treatment stimulated DNA synthesis and thercby increased the level of biosynthetic incorporation of radiolabelled fragnents. Thus it is necessary to distinguish between the various sources of radioactivity. Analysis of the purine bases by HPLC of a number of DNA samples revealed the presence of 7-methylguanine (sec tables). This methylated DNA base represented $70.92^{\prime \prime} "$ " of the total radioactivity eluted so it is clear that the administration of nitrite was, in both animal species. responsible for the formation of a DNA-methylating agent.

Experiment 2 also illustrates the very different rcsponses of individual animals. the highest value in the mouse, for example, being nearly six times the lowest value. Some important modulatory factors may be the $\mathrm{pH}$ of the stomach, the degree of satiation. and diurnal fluctuations in the rate of DNA synthesis (SchulteHermann \& Landgraf. 1974). among others. Although this brings great uncertainty to the quantitative evaluation of the data. we tried to correlate the amount of 7-methylguanine formed in experiment 2 with the amount of 7-methylguanine generated after administration of authentic $N$-nitroso $\left[{ }^{14} \mathrm{C}\right]$ dimethylamine. the methylating agent produced from DMA and nitrite. Experiment 5 (Tables 1 and 2 ) shows the 
Table 1. Formation of 7 -methylguanine in male rat liver DNA, $6 \mathrm{hr}$ after oral administration of $\left[{ }^{14} \mathrm{C}\right]$ dimethylamine. $\mathrm{HCl}$, potassium nitrite and vitamin $\mathrm{C}$

\begin{tabular}{|c|c|c|c|c|c|c|}
\hline \multirow{3}{*}{$\begin{array}{l}\text { Experiment } \\
\text { no. }\end{array}$} & \multirow{2}{*}{\multicolumn{4}{|c|}{ Treatment (mg/kg body weight) }} & \multicolumn{2}{|c|}{ Results } \\
\hline & & & & & \multirow{2}{*}{$\begin{array}{l}\text { Specific activity of } \\
\text { DNA per unit dose* }\end{array}$} & \multirow{2}{*}{$\begin{array}{l}\% \text { of } \\
\text { radioactivity } \\
\text { in } 7-M G\end{array}$} \\
\hline & {$\left[{ }^{14} \mathrm{C}\right] \mathrm{DMA} . \mathrm{HCl}$} & $\mathrm{KNO}_{2}$ & Vitamin C & {$\left[{ }^{14} \mathrm{C}\right]$ NDMA } & & \\
\hline \multirow[t]{2}{*}{1} & 0.70 & - & - & - & 4.8 & ND \\
\hline & 0.33 & - & - & - & 2.2 & ND \\
\hline \multirow{4}{*}{$\begin{array}{l}\text { Mean } \pm 1 S D \\
2\end{array}$} & & & & & $3.5 \pm 1.8$ & \\
\hline & 1.15 & 50 & - & - & 17.5 & 70 \\
\hline & 1.08 & 50 & - & - & 12.8 & ND \\
\hline & 1.12 & 50 & - & - & 7.6 & 88 \\
\hline Mean \pm ISD & & & & & $12.6 \pm 5.0$ & \\
\hline & 1.01 & 50 & 50 & - & 4.5 & ND \\
\hline $5(+$ ve control $)$ & - & - & - & $0.48 \dagger$ & 1180 & ND \\
\hline Mean $\pm 1 S D$ & - & - & - & $0.28 \ddagger$ & $\begin{array}{c}1150 \\
1165 \pm 21\end{array}$ & $>83$ \\
\hline
\end{tabular}

NDMA $=N$-Nitrosodimethylamine $\quad 7-M G=7-$ Methylguanine $\quad$ ND $=$ Not determined $;$ insufficient radioactivity for HPLC analysis of purine bases

* Specific activity is expressed as (dpm/mg isolated DNA)/(dpm/kg body weight) and the values in the table are the true values multiplied by $10^{8}$.

$+1.08 \times 10^{8} \mathrm{dpm} / \mathrm{kg}$ body weight.

$\$ 6.20 \times 10^{7} \mathrm{dpm} / \mathrm{kg}$ body weight.

results of ${ }^{14} \mathrm{C}$-labelled NDMA administration: liver DNA was highly radiolabelled and the base analysis revealed that this was predominantly due to methylations and not to biosynthetic incorporation. With these values taken as equivalent to $100 \%$ DMA nitrosation, we estimated what percentage of DMA had been converted to NDMA under the conditions used in experiment 2 with simultaneous administration of nitrite. We assumed that the dose-binding relationship was linear down to the small amounts of NDMA generated in our experiments. Good data are available to show that this is indeed the case for the gener-

Table 2. Formation of 7 -methylguanine in male mouse liver DNA, $6 \mathrm{hr}$ after oral administration of $\left[{ }^{14} \mathrm{C}\right]$ dimethylamine. $\mathrm{HCl}$. potassium nitrite and vitamin $\mathrm{C}$ or vitamin $\mathrm{E}$

\begin{tabular}{|c|c|c|c|c|c|c|c|}
\hline \multirow{3}{*}{$\begin{array}{l}\text { Experiment } \\
\text { no. }\end{array}$} & \multirow{2}{*}{\multicolumn{5}{|c|}{ Treatment $(\mathrm{mg} / \mathrm{kg}$ body weight) }} & \multicolumn{2}{|l|}{ Results } \\
\hline & & & & & & \multirow{2}{*}{$\begin{array}{l}\text { Specific activity } \\
\text { of DNA per } \\
\text { unit dose* }\end{array}$} & \multirow{2}{*}{$\begin{array}{c}\% \text { of } \\
\text { radioactivity } \\
\text { in } 7 \cdot M G\end{array}$} \\
\hline & {$\left[{ }^{14} \mathrm{C}\right] \mathrm{DMA} . \mathrm{HCl}$} & $\mathrm{KNO}_{2}$ & Vitamin C & Vitamin $E$ & {$\left[{ }^{14} \mathrm{C}\right]$ NDMA } & & \\
\hline 1 & 0.62 & - & - & - & - & 0.5 & ND \\
\hline \multirow[t]{4}{*}{2} & 0.66 & 50 & - & - & - & 1.4 & ND \\
\hline & 0.69 & 50 & - & - & - & 7.7 & 92 \\
\hline & 0.92 & 50 & - & - & - & 1.5 & ND \\
\hline & 0.98 & 50 & - & - & - & 2.6 & ND \\
\hline \multirow{5}{*}{$\begin{array}{l}\text { Mean } \pm 1 S D \\
3\end{array}$} & & & & & & $3.3 \pm 3$ & \\
\hline & 0.66 & 50 & 50 & - & - & 0.9 & ND \\
\hline & 0.56 & 50 & 50 & - & - & 0.8 & ND \\
\hline & 0.98 & 50 & 50 & - & - & 1.6 & ND \\
\hline & 0.98 & 50 & 50 & - & - & 0.8 & ND \\
\hline \multirow{5}{*}{$\underset{4}{\text { Mean }} \pm 1$ SD } & & & & & & $1.0 \pm 0.4$ & \\
\hline & 0.63 & 50 & - & 50 & - & 1.7 & ND \\
\hline & 0.68 & 50 & - & 50 & - & 0.6 & ND \\
\hline & 0.88 & 50 & - & 50 & - & 3.4 & ND \\
\hline & 0.98 & 50 & - & 50 & - & 1.8 & ND \\
\hline \multirow{3}{*}{$\begin{array}{l}\text { Mean } \pm 1 S D \\
5(+ \text { ve control })\end{array}$} & & & & & & $1.9 \pm 1.2$ & \\
\hline & - & 一 & - & - & $4.77 \dagger$ & 369 & $>99$ \\
\hline \multirow{2}{*}{\multicolumn{2}{|c|}{ Mean \pm I SD }} & & & & $1.16 t$ & $\begin{array}{c}382 \\
376+9\end{array}$ & $>95$ \\
\hline & & & & & & $3 / 6 \pm 9$ & \\
\hline
\end{tabular}

NDMA $=N$-nitrosodimethylamine $\quad 7-M G=7-$ Methylguanine $\quad$ ND $=$ Not determined $;$ insufficient radioactivity for HPLC analysis of purine bases

*Specific activity is expressed as (dpm/mg isolated DNA $) /(\mathrm{dpm} / \mathrm{kg}$ body weight) and the values in the table are the true values multiplied by $10^{8}$.

$+1.07 \times 10^{9} \mathrm{dpm} / \mathrm{kg}$ body weight.

$\$ 2.61 \times 10^{8} \mathrm{dpm} / \mathrm{kg}$ body weight. 
ation of 7-methylguanine from doses of NDMA as little as $10 \mu \mathrm{g} / \mathrm{kg}$ body weight (Diaz Gomez, Swann \& Magee. 1977). It is therefore possible to estimate that, in the rat (Table 1). $(12.6-3.5)(100 / 1165)=0.78 \%$ of the DMA had been nitrosated to yield NDMA. Due to the large individual variations. the extent of nitrosation ranged from 0.2 to $1.3 \%$. The corresponding values in the mouse (Table 2) span $0.2-1.9^{\circ} \%$ with an average of $0.75^{\circ}$, i.e. almost identical to the fraction determined in the rat.

Experiments 3 and 4 elucidated the inhibitory action of vitamin $C$ and $E$, respectively, on the nitrosation of DMA by nitrite. Because of the similarities in the above results for the rat and the mouse. replicate studies were performed only in the mouse (Table 2). Vitamin $C$ exerted a strong inhibitory effect on the generation of NDMA. After correction of the data for biosynthetic incorporation of radioactivity, it is estimated that $50 \mathrm{mg} / \mathrm{kg}$ body weight of sodium ascorbate reduced the formation of NDMA from DMA and nitrite to roughly $20^{\circ}{ }_{0}$ of the uninhibited level. However, because of the large individual variations. this inhibition was not statistically significant $(P>0.1)$. An equal dosc of $x$-tocopherol acctate reduced the formation of NDMA to about $50^{\circ}{ }^{\circ}$, of the uninhibited value, but large individual fluctuations again rendered this result statistically insignificant $(P>0.2)$. In the onc rat given vitamin $C$ (Table 1$)$. there was an apparent reduction of DNA radioactivity to background values.

\section{DISCLSSION}

The rate of formation of nitrosamines in citro at a given $\mathrm{pH}$ is proportional to the concentration of the amine and to the second power of the concentration of nitrite (Mirvish, 1975). The reaction constant, $\mathrm{k}$, is a function of the $\mathrm{pH}$ of the reaction mixture and of the nature of the amine. For DMA. the optimum $\mathrm{pH}$ is 3.4 , and the nitrosation reaction follows the equation

$$
\mathrm{d}[\mathrm{NDMA}] / \mathrm{dt}=\mathrm{k}[\mathrm{DMA}]\left[\mathrm{NO}_{2}^{-}\right]^{2}
$$

where $\mathrm{k}\left(\mathrm{pH} \mathrm{3.4)}=0.0017 \mathrm{u}^{-2} \mathrm{sec}^{-1}\right.$.

In our experiments, about $0.8^{\circ} \%$ of the dose of DMA has been converted to NDMA. If we apply the above equation to the present experiment in livo and assume a constant rate of nitrosation, we could determine the time that was necessary for this amount of NDMA to be formed. Assuming a $\mathrm{l} \mathrm{ml}$ reaction volume and a $\mathrm{pH}$ of 3.4 in the stomach, and taking the dosage used in the second rat in experiment 2 (weight $220 \mathrm{~g}$ ) as an example. we find that the reaction time, $t$, would be given by

$$
\left(2.3 \times 10^{-5}\right) / \mathrm{t}=0.0017\left(2.9 \times 10^{-3}\right)\left(1.3 \times 10^{-1}\right)^{2}
$$

thus $1=276 \mathrm{sec}$. Thereforc, a reaction time of about $5 \mathrm{~min}$ was required. This seems reasonable considering that the half-life of nitrite in the rat stomach is of the order of $10 \mathrm{~min}$ to $1 \mathrm{hr}$ (Mirvish, Patil, Ghadirian \& Kommineni, 1975). We therefore conclude that the situation in vivo in our experiments does not differ greatly from an in titro incubation reaction. This finding contrasts with the results of Rounbehler et al. (1977) who analysed cntire frozen mice for NDMA. $40 \mathrm{sec}$ to $60 \mathrm{~min}$ after oral gavage of $50 \mathrm{ng}$ DMA and
$250 \mathrm{ng}$ nitrite, and recovered up to $14 \mathrm{ng}$ NDMA. They calculated that this amount is 140 times greater than would be expected from an in vitro incubation and concluded that model studies in ritro cannot take into account the many possible competing processes in vito, including the modifying effects of inhibitors and catalysts.

Recent reports on the formation of nitrosoproline in rats and humans from dietary proline and nitrite or nitrate are consistent with our finding that in ritro reaction kinetics are not markedly distorted in vico (Ohshima \& Bartsch. 1981: Ohshima. Bereziat \& Bartsch, 1982). The similarity of the results for rats and micc in our experiments also suggests that species differences might not be so large as to prohibit the use of animal studies for risk assessments in humans. On the other hand, there were large differences between individual animals. It is to be expected that this finding will be even morc pronounced in human populations. The use of average figures may therefore be misleading and it will be necessary, in the long run, to get more information on modulatory fictors governing the many steps between the uptake of the realctants and the alkylation of DNA. Such knowledge should then also allow us to define high-risk populations and situations.

With all these limitations in mind, we can tentatively estimate the extent of liver DNA methylations in man from environmental exposure to DMA and nitrite. The dietary uptake of DMA per meal is of the order of I mg (Neurath. Dünger. Pein (t al. 1977) and the concentration of nitrite in the stomach has been reported to range from less than $2 \times 10=M 10$ more than $2 \times 10^{-3} \mathrm{M}$. depending primarily on the nitrate content in the diet (Tannenbaum. 1980). If we adopt an average of $10^{-4} \mathrm{M}$-nitrite, a reaction time of $30 \mathrm{~min}$ $(1800 \mathrm{sec})$ and an optimum $\mathrm{pH}$ of 3.4 , the concentration of NDMA generated is

$$
\left.[\text { NDMA }]=1800 \times 0.0017\left(2 \times 10^{-5}\right)(10)^{4}\right)^{2} \mathrm{M}
$$

which is about $6 \times 10^{-13} \mathrm{M}$. Thus. as little as $22 \mathrm{pg}$ NDMA are formed in $500 \mathrm{ml}$ stomach contents. This is not very much compared with the daily intake in man of preformed dietary nitrosamines. i.e. about $0.5 \mu \mathrm{g}$ NDMA (Spiegelhalder, Eisenbrand \& Preussmann. 1980), so the amount of NDMA formed in rito in the stomach seems to be negligible. The concentrations of DMA and nitrite reached in the stomachs of the animals we studied are higher than our estimates of human concentrations by a factor of at least 100 and 1000. respectively. The concentration of NDMA formed was therefore about $10^{8}$ times higher in our experiment compared with the normal situation in man. Our system is not sensitive enough to be used with much lower concentrations. For greater sensitivity it would be necessary to use an amine with a higher reaction constant. $k$, such as aminopyrine, which readily generates NDMA on reaction with nitrite. We are currently investigating this reaction with lower concentrations of nitrite and studying the conversion of nitrate to nitrite.

\section{REFEREYCES}

Asahina S.. Fricdmann M. A. Arnold E.. Millar (i. N. Mishkin M., Bishop Y. \& Epstcin S. S. 119711. Acuti 
synergistic toxicity and hepatic necrosis following oral administration of sodium nitrite and secondary amines to mice. Cancer Res. 31, 1201.

Braun R., Schöneich J. \& Ziebarth D. (1977). In vito formation of $N$-nitroso compounds and detection of their mutagenic activity in the host-mediated assay. Cancer Res. 37, 4572.

Cardesa A. Mirvish S. S., Haven G. T. \& Shubik P. (1974). Inhibitory effect of ascorbic acid on the acute toxicity of dimethylamine plus nitrite in the rat. Proc. Soc. exp. Biol. Med. 145. 124.

Dahn H., Loewe L. \& Bunton C. (1960). Ueber die Oxydation von Ascorbinsäure durch salpetrige Säure. Teil VI: Uebersicht und Diskussion der Ergebnisse. Helt. chim. Acta 43, 320.

Diaz Gomez M. I., Swann P. F. \& Magee P. N. (1977). The absorption and metabolism in rats of small oral doses of dimethylnitrosamine. Implication for the possible hazard of dimethylnitrosamine in human food. Biochem. J. 164, 497.

IARC (1980). N-Nitroso Compounds: Analysis, Formation and Occurrence. Edited by E. A. Walker, L. Griciute, M. Castegnaro \& M. Börzsönyi. IARC Scient. Publ. no. 31. International Agency for Research on Cancer, Lyon.

Lawley P. D. (1976). Methylation of DNA by carcinogens: Some applications of chemical analytical methods. In Screening Tests in Chemical Carcinogenesis: Proceedings of a Workshop Organized by IARC and the Commission of the European Communities and held in Brussels, Belgium, 9-12 June 1975. Edited by R. Montesano, H. Bartsch \& L. Tomatis. IARC Scient. Publ. no. 12, p. 181. International Agency for Research on Cancer, Lyon.

Markov G. G. \& Ivanov I. G. (1974). Hydroxyapatite column chromatography in procedures for isolation of purified DNA. Analyt. Biochem. 59, 555.

Mirvish S. S. (1975). Formation of $N$-nitroso compounds: Chemistry, kinetics, and in vivo occurrence. Toxic. appl. Pharmac. 31, 325.
Mirvish S. S., Patil K., Ghadirian P. \& Kommineni V. R. C. (1975). Disappearance of nitrite from the rat stomach: Contribution of emptying and other factors. $J$. natn. Cancer Inst. 54, 869.

Neurath G. B., Dünger M., Pein F. G., Ambrosius D. \& Schreiber O. (1977). Primary and secondary amines in the human environment. $F d$ Cosmet. Toxicol. 15, 275.

Ohshima H. \& Bartsch H. (1981). Quantitative estimation of endogenous nitrosation in humans by monitoring $\mathrm{N}$-nitrosoproline excreted in the urine. Cancer Re's. 41, 3658.

Ohshima H., Bereziat J.-C. \& Bartsch H. (1982). Monitoring $\mathrm{N}$-nitrosamino acids excreted in the urine and feces of rats as an index for endogenous nitrosation. Carcinogenesis 3, 115.

Pollard M., Sharon N. \& Chang C. F. (1972). Synthesis of hepatotoxic agents in germfree and conventional mice which had been fed $\mathrm{NaNO}_{2}$ and dimethylamine. Proc. Soc. exp. Biol. Med. 140, 1073.

Rounbehler D. P., Ross R., Fine D. H., Iqbal Z. M. \& Epstein S. S. (1977). Quantitation of dimethylnitrosamine in the whole mouse after biosynthesis in vivo from trace levels of precursors. Science. N.Y. 197, 917.

Schulte-Hermann R. \& Landgraf H. (1974). Circadian rhythm of cell proliferation in rat liver: Synchronization by feeding habits. $Z$. Naturf. 29C, 421.

Singer B. (1975). The chemical effects of nucleic acid alkylation and their relation to mutagenesis and carcinogenesis. Progr. Nucl. Acid Res. 15, 219.

Spiegelhalder B., Eisenbrand G. \& Preussmann R. (1980). Volatile nitrosamines in food. Oncology 37, 211.

Tannenbaum S. R. (1980). Ins and outs of nitrites. The Sciences 20,7.

Viviani A. \& Lutz W. K. (1978). Modulation of the binding of the carcinogen benzo(a)pyrene to rat liver DNA in vivo by selective induction of microsomal and nuclear aryl hydrocarbon hydroxylase activity. Cancer Res. 38, 4640. 